\title{
Chapter 1: The Helios School - Inclusive University School in the City of Cologne
}

\author{
Kersten Reich ${ }^{1}$ \\ ${ }^{1}$ University of Cologne, Faculty of Human Sciences, Cologne, Germany \\ Correspondence: Kersten Reich, University of Cologne, Faculty of Human Sciences, Gronewaldstraße 2, 50931 \\ Cologne, Germany. E-mail: Kersten.Reich@uni-koeln.de
}

Received: May 25, 2017

Accepted:September 1, 2017

Online Published: March 7, 2018

doi:10.5430/irhe.v3n 1p4

URL: https://doi.org/10.5430/irhe.v3n1p4

\begin{abstract}
My essay introduces the model of the Inclusive University School of Cologne, established in 2015, that intends to be a contemporary model of democratic school in the Deweyan tradition based on principles of participation and diversity under the complex life conditions of today. The text contains four components: First, I will reconstruct some elements and principles from Dewey's Chicago Laboratory School that served as a basis for the Inclusive University School of Cologne. Secondly, I will give a comprehensive account of the inclusive concept of the Cologne school and the ways it works out in practice. Third, I will elaborate on the pedagogical program of the school formulated in ten components of inclusive learning and teaching. In a fourth step, I will give a concrete account of what "new learning" means in the context of this new school. Finally, I will discuss some main obstacles that we encountered and had to overcome in establishing the school in Cologne.
\end{abstract}

Keywords: inclusive education, Chicago Dewey School, new learning, democratic school

\section{Introduction}

This chapter presents the Inclusive University School of Cologne, founded in 2015, as a model for a prag matist and constructivist way of realizing democracy and education today. It provides an example for inclusive learn ing and teaching under conditions of liquid modernity and in the context of irreducible diversity and complexity in contemporary social life. I will proceed in the following steps: First, I will take a look back in history and focus on some essential fundaments of democratic and inclusive schooling in the Deweyan tradition starting with the famous Chicago University School. Second, I will give a systematic account of the necessary ten components of inclusive schooling based on contemporary debates and the Cologne program of inclusive teaching. Third, I will elaborate on the reconstructed version of the learners' laboratory contained in present day constructive learning environments, including the four dimensions of "learn ing landscapes," "learning projects," "learn ing workshops," and "dialogic al instruction." I will discuss each dimension in its implications for learning environments including such factors as social interaction, communication, participation, and temporal and spatial resources and structures of learning. Fourth, the example of the recently founded public school in Cologne will highlight some crucial challenges and problems on the way of realizing the inclusive and democratic approach in practice, including administrative and political processes and obstacles in the traditionally very exclusive German educational system. All four steps will be connected with the theoretical perspectives, which will be elaborated in greater detail in the following essays in this collection.

\section{John Dewey's Laboratory School as a Model for Cologne}

In his book The School and Society (MW 1: 1-109), (Note 1) first published in 1900, Dewey presented the model of a laboratory school connected with the university of Chicago that in cluded a completely new approach to learn ing as a part of democracy. In his view the traditional model of learning by instruction in hierarchical structures and dependencies provided too little opportunity for individual learners to partake in social processes of interaction, communication, and problem solving. In contrast to the traditional "monastery" approach of bookish learning the new school should emphasize insights of progressive education and support new ways of learning socialization that further individual capacities of participating in diverse ways of individual and social growth. His practical model of the school as a laboratory of society - what he called a "miniature commun ity" or "embryonic society" - anticipated his later theoretical approach to Democracy and Education (MW 9). Garrison, Neubert and Reich (2016) argue that 
the Deweyan tradition is still relevant today not only for the democratic reconstruction of learning, teaching, and socialization (schooling), as well as on a broader scale the necessary renewal of participatory and plu ralistic ways of human living together under conditions of social equity. In Germany, Dewey's model was constitutive, among other things, for the foundation of the Bielefeld Laboratory School by Hartmut von Hentig who copied the concept as well as many details. (Note 2) Another and different approach that connects much more explicitly with Dewey today is the Helios-School in Cologne. This school has been founded under the influence of the Dewey Center at the University of Cologne established by Larry Hickman, myself and Stefan Neubert. The Center participates in international research, exchange, and application of pragmatist philosophy and education from a constructivist perspective. Its works and publications have provided conceptual and theoretical grounds for the practical work done at the inclusive school. This applies, among other things, especially for the democratic organization of relationships under conditions of diversity, the communicative and cooperative approach to teaching and learning, and the participatory model of school life. (Note 3) Starting with the process of school foundation, all elements and principals of the inclusive school have been deliberately organized by processes of participation, including such agents like the teachers, principals, university experts, students, parents, educational policy makers, city and county administrators, architects, investors and local and urban communities. Public participation, deliberation, and decision making played a constitutive role in the school foundation from the very start. For example, influential interests supported the plan of constructing a shopping mall on the grounds, first. It was only because of public protest and the majority will of people living in the district that these plans were rejected in a formal process of decision making on behalf of establishing the school. The particular interests of investors in this case drew the short straw against the broader public interests of local inclusive schooling. Likewise, the internal development of the school as a concept and a practical model was guided by processes of "deep democracy" (Green 1999) that were based on the cooperative solution of problems and challenges by the community of all involved.

Two main problems had to be faced in the process of foundation:

(1) The first problem was that the traditional German school system is based on principles and procedures of selection to a degree that is extraordinary compared with many other countries. This is apparent in the notoriously high correlation between social status and educational achievements. It poses serious threads to the realization of social equity and equal chances and puts fundamental democratic principles at risk. A general reconstruction of education and the educational system seems to be imperative although the political will as well as public opinion so far still largely supports the older system and the will to inclusion and more equity in education is at best ambivalent. In this context, the foundation of an inclusive and participatory university school aimed at increased equity and appreciation of diversity is a paradoxical project. It anticipates on a small scale what can only be achieved, in the long run, in society at large. This is the very paradoxical challenge that Dewey already addressed when he called his text "The School and Society."

(2) The second problem consisted in the traditional German system of teacher education. A thoroughgoing separation of theoretical and practical teacher training has always been the rule. To counter this one-sided tradition, students and experts cooperatively looked for alternatives based, among other things, on experiences from Scandinavian teacher train ing schools. Partly influenced by student exchange programs like ERASMUS, these experiences were articulated by students who unified their perspectives and interests under the slogan "school is open."

Against the background of these main and many other detail problems, the foundation of the new school demanded intensive processes of "change management" that included many complex theoretical, conceptual, practical, and organizational endeavors and even struggles. As the scientific director and coach of the process I had to cooperate with many partners including the students, and to negotiate between powerful interests like the university and city administration, investors, policy makers, architects, supporters, and the public. A crucial component in these complex processes of negotiation and decision-making was the "Committee for the Foundation of the Inclusive School" that combined representatives of all relevant interests on a voluntary basis. This committee itself had to be open as well as inclusive, and pains were taken that all involved perspectives were taken seriously and discussed openly. Processes of conflict resolution had to be self-regulated and self-determined. The interesting thing is that the very vision of creating a new and better school was sufficient upon the whole to motivate all participants to find constructive solutions even to complex problem. (Note 4) The conceptual frame of the project has thus been constructed and reconstructed many times in cooperation and discussion based on preliminary work already published (Reich: 2012, 2014). 
If we look back today at Dewey's Laboratory School in Chicago, we find many commonalities in theory, concept, practice, organizational structure, and even architectural design. Upon the whole, this comparison shows how troublesome and tedious the process of educational reconstruction is - especially if it is to be generous and sustainable. Like Dewey, the founders of the Cologne inclusive school were convinced that educational reconstruction must provide opportunities for individuals to enhance their cooperative, communicative, constructive, and participative capacities and competencies, not only to grow as individuals but at the same time contribute to social growth and living together in diversity. They also shared Dewey's insight that this is not only a challenge of education and schooling in the narrow sense, but a larger social challenge to realize democracy in all areas of life. It presupposes public will as well as political decisions including the necessary funding by the state as the primary democratic agent of education. "What the best and wisest parent wants for his own child, that must the community want for all of its children. Any other ideal for our schools is narrow and unlovely; acted upon, it destroys our democracy" (MW 1:5). Education in this sense must combine individual as well as social interests and perspectives. The democratic ideal will be betrayed to the degree in which the rights of property on behalf of the few get the better against the interests of the multitude. What is more, those who are disadvantaged in a system of social and educational inequality often even lack the resources and capacities of articulating their interests as "wise parents" on equal terms. Therefore, it is the responsibility of educational systems and politics to compensate as far as possible for social inequality and compartmentalization through measures of participation, support, and inclusion. "All that society has accomplished for itself is put, through the agency of the school, at the disposal of its future members. All its better thoughts of itself it hopes to realize through the new possibilities thus opened to its future self. Here individualism and socialism are at one. Only by being true to the full growth of all the individuals who make it up, can society by any chance be true to itself' (ibid.).

Dewey is very clear that democracy and education must counter tendencies to privilege particular interests of the few over the legitimate interests of full and inclusive participation for all. Democracy is an ideal that gives orientation for this program even if society at large is characterized by many forms of social inequality as it was in Dewey's time and is in ours. The declaration of human rights, the success of democratic institutions, the continual struggle for participation and equal opportunities bear witness that this ideal is not just illusionary, even if democracy remains a contingent project that is continually put at risk by many social forces. For instance, Dewey was already aware of the problematic tension between democracy and capitalis $m$ in his age that produced many examples of privileged interests that dominate over the claims of the common good. Up to our time, the gap between the rich and the poor has even grown (cf. Stiglitz 2012). Other forms of social divide haven taken new forms like the gap between men and women, educated and uneducated, the west and the rest, the north and the south. The struggles for equitable conditions of life as a precondition for the democratic participation of all continues and must respond to these new constellations. The decoupling of social background and educational achievements is one of the main challenges in this connection.

In this context, education and schooling still play a central role. The crucial challenge here lies not so much in reconstructing techniques of instruction and learning as important as these are in all concrete practices. More important, however, is to nurture a culture of appreciation of diversity, inclusive practices, relationships of mutual care, opportunities of participation for all in school life. This includes explicit communal and educational policies that respond to specific contexts and local conditions as well as global challenges. It equally includes a clear awareness of the necessity to struggle for more social equity and justice in the concrete practices of education and schooling. It cannot be emphasized enough that this attitude is a main condition for the success of inclusion in education as well a society at large.

Dewey's The School and Society is a response to the typical modern tendency to separate schooling from real life. He believed that this very separation was a thread to democracy because it disconnected formal learning from everyday life and everyday forms of social participation and intercourse. It added to the compartmentalization of life in solid modernity that separated work from leisure, doing from knowing, labor from management, luxury from poverty, political elites from the masses, etc. In school itself, the compartmentalization shows in the division of disciplines in the curriculum, in the tendency to regard the teacher as his or her own master in his or her own classroom, in the aloofness of bookish learning and the individualization of achievements measu red by grades. It is a paradox of teaching and learning today that teachers and learners are often captured between solid and liquid modernity (see Jim Garrison's more detailed discussion in chapter 3). This is to say the social conditions under which teaching and learning take place are largely liquefied while the claims and structures show many traces of much more solid conditions. Think of the hierarchical structures of decision making in many contemporary school systems, notoriously in Germany. Think of the overwhelming majority of school buildings world wide that show an 
architectural design that resembles the military casern or the prison. Think of the still dominant rigid rhythm of timing that follows the ringing of the bell. These are all very useful measures to prepare school for the most solid forms of instruction that modernity has invented. But for the very same reason they increasingly lose their viability to the degree that schooling has to be connected with and must respond to conditions of liqu id life (see Bauman 2000).

Against this background, Dewey's whole educational approach and especially his concept of a laboratory school largely anticipated the transition from solid to liquid modern ity that Bauman, in retrospect, describes as the central development of $20^{\text {th }}$ century history. In this sense, he was ahead of his time while he responded to the contradictions of capitalis $m$ and democracy and tried to find a way to forward the democratic project under conditions of solid modernity. Interestingly, especially for the history of schooling, he anticipated necessary forms of educational reconstruction, that to justice to the liquefied conditions of life, increased individualization, more dynamic forms of social and cultural diversity in migration societies, new forms of cooperation and communication, increased interdependences between local communities and global networks. One core idea for making education more liquid that up to the present day has not sufficiently been realized is Dewey's plan to overcome rigid separations of disciplines and contents of learning by focusing on inter- and transdisciplinary projects or what he calls "occupations" in The School and Society: "The occupation supplies the child with a genuine motive; it gives him experience at first hand; it brings him into contact with realities. It does all this, but in addition it is liberalized throughout by translation into its historic and social values and scientific equivalencies. With the growth of the child's mind in power and knowledge it ceases to be a pleasant occupation merely, and becomes more and more a medium, an instrument, an organ of understanding - and is thereby transformed." (MW 1:15)

This implies a fundamental turn from teacher centered and textbook centered methods to "learning by doing" in the sense of learning by experience as the connection of doings and undergoings in interaction with other learners. Dewey's insight that democracy must be reinvented as well as reconstructed by each generation according to the challenges of their time includes the understanding that education, too, must change according to new contexts of living. It is imperative for the success of this turn that the school be conceived as itself a small society in its own ways, a community of learners, or in Dewey's words an "embryonic society" and "miniature community" (MW 1: 12). This is because to take the turn all partakers in school life must have the opportunity to make their own unique contribution to the reinvention of schooling through forms of direct participation, benevolent cooperation, and generous communication. In this sense the reconstruction of school is built on the process of experiencing and at the same time experienced by all. It is part of Dewey's constructivist approach that he combines the phases of primary experience (doing and undergoing) and secondary experience (reflection) in his analysis of human learning and knowing. For the school this implies, from the perspective of Cologne constructivism, that all partakers in the reform of schooling must have sufficient opportunities to be participants as well as agents and observers in and of the ongoing process. We must, then, see the school as a learning organization that can only learn successfully and sustainably in a democratic sense to the degree that it allows for generous participation of all. The concept of occupation is Dewey's way to formulate this crucial inclusive insight.

If we look back at the last hundred years of research on learning, we find that Dewey already explained what todays is often seen as an essential new result: the idea that only a diversity of perspectives, accesses, and results in learning can do justice to the diversity of learners and their unique experiences. We may call this the incommensurability principle of learning. Dewey comes to this understanding because he always conceives of learning by including the perspectives of the learners themselves into his considerations. For this reason, he suggests the following general interests that learners themselves bring into the process of learning (MW 1: 29-30): "If we roughly classify the impulses which are available in the school, we may group them under four heads."

First, there "is the social instinct of the children as shown in conversation, personal intercourse, and communication ... [The] limited interest of little children is in this manner capable of infinite expansion. The language instinct is the simplest form of the social expression of the child. Hence it is a great, perhaps the greatest of all educational resources." Dewey here uses the term "instinct" that was usual in the vocabulary of his time to denote native impulses in humans. From the perspective of today, though, the name "impulse" seems more appropriate. Even Dewey himself, in his later writings, abandoned the term instinct and systematically replaced it by "impulse" e.g., in "Art as Experience."

Second, "there is the instinct of making - the constructive impulse. The child's impulse to do finds expression first in play, in movement, gesture, and make-believe, becomes more definite, and seeks outlet in shaping materials into tangible forms and permanent embodiment." 
Third, Dewey observes an "instinct of investigation" that "seems to grow out of the combination of the constructive impulse with the conversational. There is no distinction between experimental science for little children and the work done in the carpenter shop. Such work as they can do in physics or chemistry is not for the purpose of making technical generalizations or even arriving at abstract truths. Child ren simply like to do things, and watch to see what will happen. But this can be taken advantage of, can be directed into ways where it gives results of value, as well as be allowed to go on at random."

Fourth, "the expressive impulse of the children, the art instinct, grows also out of the communicating and constructive instincts. It is their refinement and full manifestation. Make the construction adequate, make it full, free, and flexible, give it a social motive, something to tell, and you have a work of art."

Dewey concludes: "Now, keeping in mind these fourfold interests - the interest in conversation or communication; in inquiry, or finding out things; in making things, or construction; and in artistic expression-we may say they are the natural resources, the uninvested capital, upon the exercise of which depends the active growth of the child."

Dewey takes these categories out of observations in his Chicago Laboratory School. He does not claim empirical validity but the educational psychology of our time supports his general account and backs it up with empirical studies (cf. Hattie 2009). Dewey's intention was to suggest that the school of his day does not do justice to the preconditions and experiences of learners regarding among other things these four general resources. He introduced his own reconstructed model of school against the background of his own awareness of the history of school in Western societies. Since the beginning of modernity, there has been a strong tendency towards separating schooling from life. The more complex modern societies became, the more remote schooling tended to be from affairs of common daily life outside the school-world. One of the revolutionary aspects in his Chicago Laboratory School was the idea that the reconstruction of school should begin with architecture. He anticipated and justified the even today very innovative and hardly realized conviction that the needs, aims, and claims of educ ation should condition school architecture and not vice versa. Dewey represented the ideal-typical scheme for the reconstructed school among other things in the following pictures (MW 1: $48 \mathrm{ff}$.$) :$
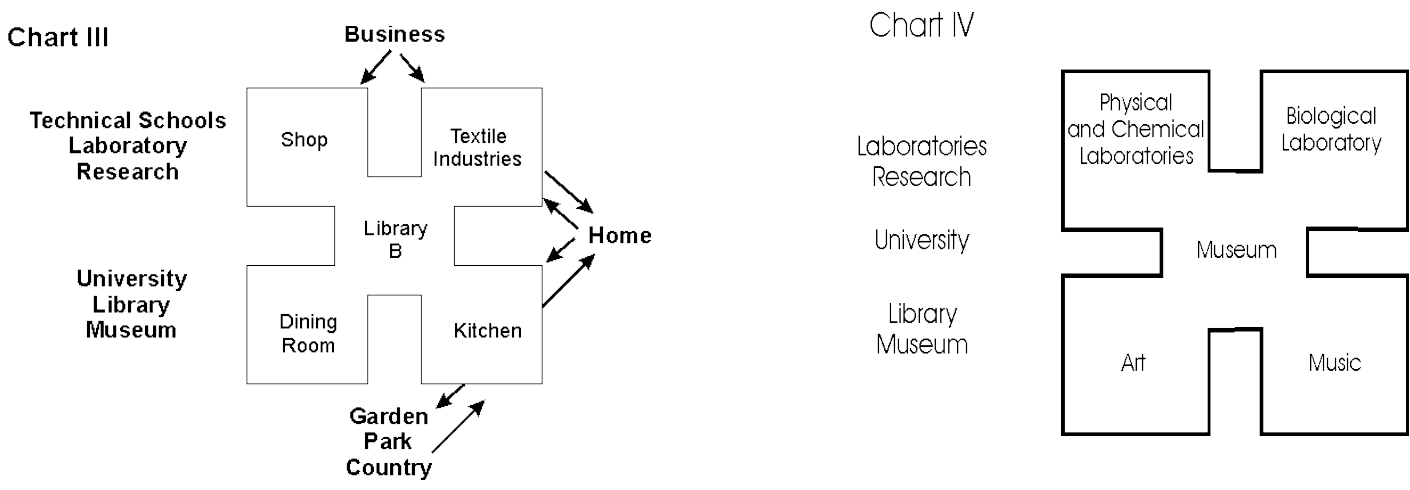

Figure 1. Chicago Laboratory School Chart III and IV

Chart III portraits the basic floor where experiences from out of school are connected with the work and learning within the school. It is a regular practice of the school to connect with the larger social, urban and natural surroundings and use them as significant learning environments for all children. For example, when studying food and the preparation of meals, learning includes visiting farms, other workplaces, groceries, markets and so on. In the school there is a kitchen and a dining room together with shops for diverse activities including work with a variety of materials like textile industries. The general principle of teaching and learning is what Dewey called "occupations" based on "learning by doing." The chart indicates that such learning never starts from books and the curriculum alone. Rather it is an interaction between "The Child and the Curriculum" (MW 2: 271-291) in the sense that learners interact with peers as well as teachers and parents and other persons from the community. Learning should grow out of the participation of all learners, and the art of teaching consists in connecting their diverse experiences and life-worlds with the necessary contents of learning. This is the reason why the library as the icon of sedimented knowledge in culture is placed in the middle of the building. It is a place of assembling as well as passing through in 
the course of diverse learning activities. Occupations never start here, but the depths and horizons of learn ing can be extended and enriched by making use of the accumulated cultural resources. "If the four corners represent practice, the interior represents the theory of the practical activities." (MW 1: 48) The interactive process of learning is especially represented through the idea of "recitation rooms." In Dewey's time, this room was usually a place for reproducing knowledge learnt by heart. In his laboratory school, Dewey introduces a totally new concept: If "you imagine rooms half in the four corners and half in the library, you will get the idea of the recitation room. That is the place where the children bring the experiences, the problems, the questions, the particular facts which they have found, and discuss them so that new light may be thrown upon them, particularly new light from the expe rience of others, the accumulated wisdom of the world-symbolized in the library. Here is the organic relation of theory and practice; the child not simply doing things, but getting also the idea of what he does; getting from the start some intellectual conception that enters into his practice and enriches it; while every idea finds, directly or indirectly, some application in experience, and has some effect upon life. This, I need hardly say, fixes the position of the 'book' or reading in education. Harmful as a substitute for experience, it is all-important in interpreting and expanding experience." (MW 1: 51)

Chart IV represents the more abstract and intellectual and esthetical ways of knowledge production and creative as well as critical reconstructions of experiences. Here we find science laboratories as well as rooms for art and music. "All art involves physical organs--the eye and hand, the ear and voice; and yet it is something more than the mere technical skill required by the organs of expression. It involves an idea, a thought, a spiritual rendering of things; and yet it is other than any number of ideas by themselves. It is a living union of thought and the instrument of expression. This union is symbolized by saying that in the ideal school the art work might be considered to be that of the shops, passed through the alembic of library and museum into action again." (MW 1: 52) The museum is the place where accumulated work of industries, sciences, and arts is available for understandings necessary cu ltural and his torical contexts of learning.

One illustration of learning through occupations and learn ing by doing in the Chicago laboratory school of Dewey's day can be taken from photos at its website today. Here is one example: "Elementary geography cla ss. Laboratory School. Education through experience formed the foundation of the Laboratory School curriculum. Students learned practical skills from weaving to woodworking to sculpting. Science was mastered in the garden as well in the classroom, where sandboxes offered opportunities for individual experiments in landforms and erosion." (Note 5)

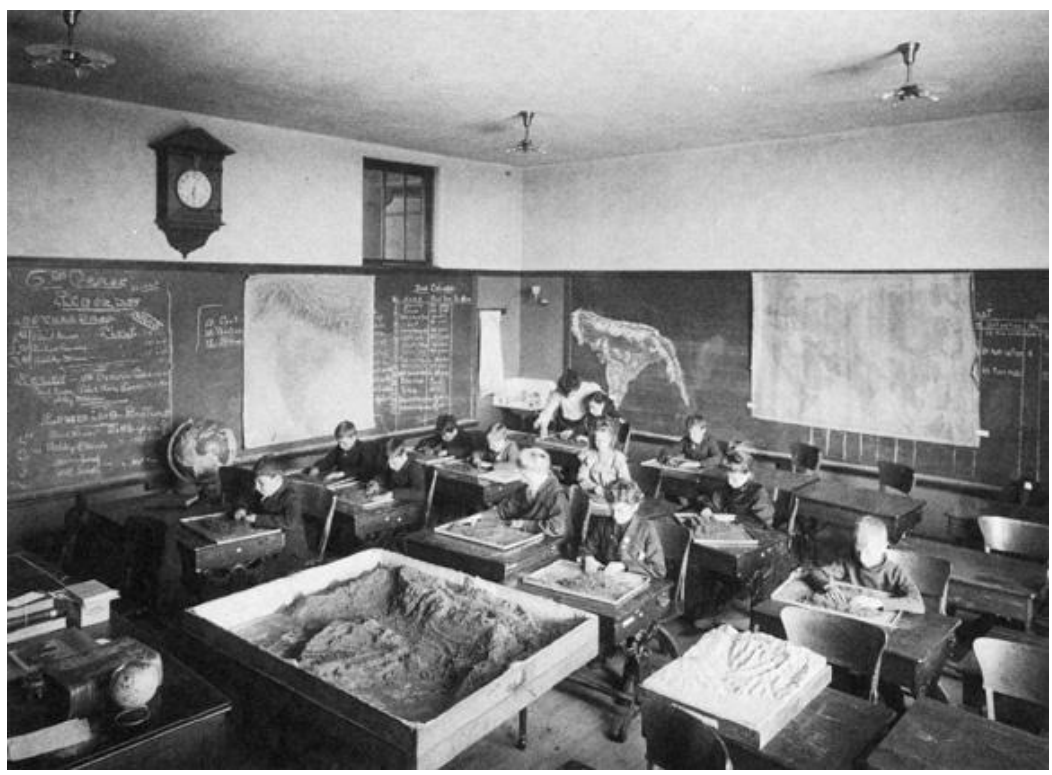

Figure 2. Chicago Laboratory School "Elementary Geography Class"

The laboratory school was part of the University of Chicago and charged tuition fees for the students of the elementary school (cf. MW 1: 58). As a private school, it could well serve as an educational laboratory but not as a general model for public schools. Dewey was well aware about the conditions and problems of private schooling and 
about the limits of the Chicago school regarding a broader realization of democracy and education in the public school system. His whole idea of educational reconstruction, however, necessarily addressed schooling as a general challenge and task of society. This is why his later book "Democracy and Education" (MW 9) is not confined to reflecting the results of the Chicago experiment but elaborates much more comprehensive perspectives and approached to public education.

More than 100 years after the foundation of the Chicago laboratory school the inclusive university school in Cologne has been founded as a public school connected to the university and free from tuitions. The school admin istration and funding is, as typical for Germany, in the hands of civic educational policy including local, regional, and state levels.

Despite these differences of context, it is striking, though, that some fundamental challenges are very much alike today compared to those that had to be faced in the Chicago project. Most important are the following:

(1) "What can be done, and how can it be done, to bring the school into closer relation with the home and neighborhood life - instead of having the school a place where the child comes solely to learn certain lessons? What can be done to break down the barriers which have unfortunately come to separate the school life from the rest of the everyday life of the child?" (MW 1: 59)

(2) "What can be done in the way of introducing subject-matter in history and science and art, that shall have a positive value and real significance in the child's own life; that shall represent, even to the youngest children, something worthy of attainment in skill or knowledge; as much so to the little pupil as are the studies of the high-school or college student to him?” (Ibid.)

(3) "How can instruction in these formal, symbolic branches - the mastering of the ability to read, write, and use figures intelligently - be carried on with everyday experience and occupation as their background and in definite relations to other studies of more inherent content, and be carried on in such a way that the child shall feel their necessity through their connection with subjects which appeal to him on their own account?" (MW 1: 60)

(4) How can individual attention to learners be provided? (cf. ibid.)

The concept of a laboratory school (Chicago) or an inclusive school (Cologne) responds to these challenges that even today include many unresolved problems. Dewey points to one basic precondition for any promising response: The chances of success are higher if individual attention "is secured by small groupings - eight or ten in a class - and a large number of teachers supervising systematically the intellectual needs and attainments and physical well-being and growth of the child." (MW 1: 60) Even though this standard may still seem utopic regard ing the public school systems in our time, it gives orientation for the direction in which schooling should proceed. As a public school, the inclusive university school in Cologne cannot come up to this standard regarding teacher learner ratio. This is a privilege of some especially well funded and elitist private schools in our days. But the IUS has found a way to combine measures for improving the teacher learner ratio with innovative and experience based approaches in teacher education. This intensifies the professionalization of teachers already at the university level as well as increases the teaching forces in the school. Teacher students during their MA studies must complete a half year internship I $n$ a public school. A large number of them do this in the IUS so that as a rule each teacher cooperates with one teacher student at the very end of his or her university studies. This adds to the profound education of teacher students, and it almost improves the teacher learner ratio by the factor two.

Part of Dewey's response to the four challenges was his learning concept of occupations. In his time th is included to a large degree manual work and skills. In his shops work with textiles, wood, metal, and other materials dominated according to the prevailing industries and modes of production. With the huge changes of all conditions of human life during the last century-including economic systems, technologies and sciences, modes of production and consumption, digitization, globalization-it is obvious that the challenges as well as possible responses to them have also changed in many important details. In general, the concept of the IUS connects with the idea of learning by occupations in the Deweyan sense, but the early $20^{\text {th }}$ century model of shops has been further developed to learning environments that include more contemporary materials, tools, and ways of producing knowledge. Among other things, the scope of necessary cultural skills and competencies - what in Dewey's time was largely the three R's - has increased immensely. What is more, the complexity of social life has also grown in unprecedented ways. Therefore, problem based learning today often needs to be accompanied by much more contextualization and background information. This changes the very concept of occupations as a learning principle and it requires more connecting steps between immediately experienced problems and necessary context information for understanding and solving the problems. In this connection, a twofold response is necessary to meet the challenge. On the one hand, 
we have to take pains that the necessary practical components in learning are not swallowed up by the sheer mass of supposedly indispensable subject-matter. We have to safeguard experience against mere reproduction of information, learning by doing against learning only for the test. On the other hand, we have to invent new methods and approaches for including increasingly complex contexts into immediately practical experiences of learners. Tony Booth argues (in Reich 2012) that schooling in the future must be focused around genetic themes of human life like water, nutrition, globalization, climate, peace, equity, and many others. The challenge is to overcome the reductionisms of narrow specialization - in science as well as in education-and to explore these themes in interand transdisciplinary ways including their multiple and interconnected contexts. Classical school disciplines can hardly do the job and we have to reinvent the structures and organization of learning in order to strengthen the learners' powers to comprehend complexity in a timely way. The affinity to Dewey's intentions and general approach could not be more obvious. If we conceive learning primarily from the perspective of the learner, the all-decisive thing is that his or her interactions with significant environments are the starting points for learning. Dewey observes: "There is very little place in the traditional schoolroom for the child to work. The workshop, the laboratory, the materials, the tools with which the child may construct, create, and actively inquire, and even the requisite space, have been for the most part lacking." (MW 1:22) This essential insight has to be contextualized in every time anew. The IUS is one model of contextualization in our time.

\section{The Helios School as Inclusive University Teacher Training School}

The ideas and approaches contained in the conceptual frame of the Cologne Inclusive University School (IUS) not only draw on Dewey, but also include many other results from international educational reform projects as well as research on teaching and learning since his time. Like Dewey and his Chicago colleagues, we reinvent the school today by using models that other agents have already successfully tried out. There is a number of prize-winning schools in Germany that have inspired us. We have adopted some formats of teaching and learning which they had already successfully put into practice. Given that the very structure and architecture of the IUS had been devised according to our educational principles, we found ourselves in the fortunate situation that we could realize these approaches and formats in more consequential ways than many other schools can. The construction of the building as well as the shaping of all learning spaces was designed after the inclusive scheme. We take it as our obligation to continually and comprehensively inform the public of the city and the state about all relevant successes and difficulties that we encounter in the ongoing process of establishing the school from bottom up.

The opportunity to found an inclusive university school in Cologne was given since 2009 when the German Government signed the United Nations' Convention on the Rights of Persons with Disabilities. Traditionally the German school system is very selective, excluding almost all students with special needs from the general educational institutions. There exists a complex system of special needs schools that are characterized by low achievements and low chances of getting substantial degrees. Therefore, inclusion of persons with disabilities into the regular school system poses a huge challenge. What is more, the IUS employs a broad understanding of inclusion according to international standards. This involves to envision inclusion as a comprehensive strategy against discrimination not only addressed to issues of disabilities but also differences of gender, social status, cultural and ethnic background as well as sexual orientation. In Germany, it is very clear that these differences are highly intersected. For example, in many cases poor social status is correlated with backgrounds of migration and even educational exclusion from the regular school. The fundamental principle of dealing with heterogeneity in the IUS is to roughly represent diversity of all kinds in society within the heterogeneity of the learning groups in school. Especially, the school is coordinated and interrelated with the urban context and characteristics of the neighborhood. 


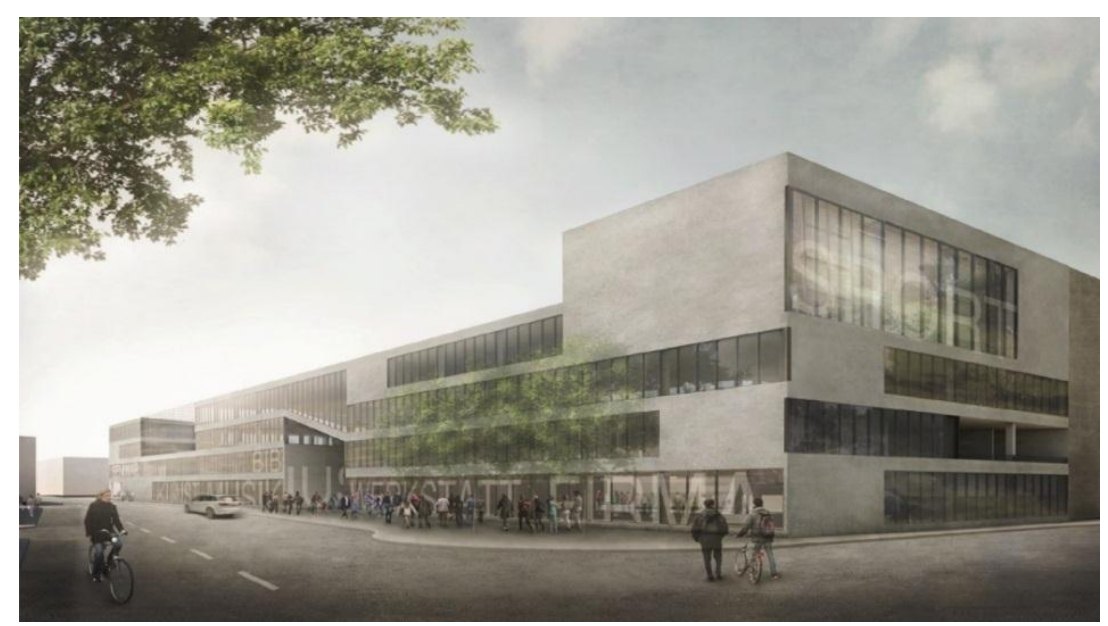

Figure 3. The front of the "Helios-School IUS" by Schilling architects. At the base are rooms like student companies accessible to the public

Although connected with the university, the IUS is a public school located in Cologne urban neighborhood (Ehrenfeld) characterized by broad social, cultural, economic, re lig ious diversity. The university connection consists of the following three parts: First, the school serves as a teacher training school for a large group of Cologne teacher students. Second, the university provides accompanying research to the school development. Third, projects organized in cooperation between the school and the university contribute to international research in teaching and learning. The school's very policy has from the start been to locate itself in the international contexts of school development including many forms of cooperation with schools, universities, and research networks worldwide.

The Inclusive University School - also called Helios School after a former factory on the location of the new school building - is a comprehensive school extending from grade one to thirteen. When completely build up, the school will comprehend roughly 1.100 students. It includes the German components of primary and secon dary schooling. Primary education comprises grades one to four, secondary includes grades five to ten (secondary phase one) which prepares for secondary school leaving certificate, and grades eleven to thirteen (secondary phase two) which prepares for university level. On the primary level, there is no strict separation of grades. The core principle is a process of grouping across ages six to ten in stem groups. On the secondary level, there are also stem groups but these are of same age. Grades one to four are placed into two parallel classes, grade five to thirteen are placed into four parallel classes. This is because the school wants to give children from other primary schools the chance to join it for their secondary education.

In all grades, there are no classrooms in the traditional sense but learning landscapes adapted to the diverse needs of diverse learners and open possibilities for flexible processes of learn ing for individuals and groups. For each learning landscape with about 100 students, there is a multi-professional team with teachers, educators, special needs educators, social workers, therapists, teacher students, and other cultural workers. The teams consist of roughly twelve experts including seven to eight teachers. All educational proces ses are assisted and supervised by all members of the team. Therefore, the staff student ratio is extraordinarily fortunate ranging between eight to ten students per expert. Especially for the German context, the fact is extraordinary that all experts are obliged to be present in the schoolall day.

\section{Components of Inclusive Teaching and Learning}

The school's policy (cf. Reich et al 2015) is built on ten components contained in Reich's (2014) prag matist and constructivist approach of „Inclusive Teaching and Learning.“ The table gives an overview. In the following section I will give an example that illustrates the here stated principles and measures: 


\begin{tabular}{|c|c|c|}
\hline $\begin{array}{l}\text { Com- } \\
\text { ponent }\end{array}$ & $\begin{array}{l}\text { Guiding } \\
\text { principles for } \\
\text { inclusive } \\
\text { teaching } \\
\text { learning }\end{array}$ & Examples of concrete measures \\
\hline 1 & $\begin{array}{l}\text { An inclusive } \\
\text { learning culture } \\
\text { with focus on } \\
\text { mutual relations } \\
\text { of care and } \\
\text { support, } \\
\text { appreciation of } \\
\text { diversity, } \\
\text { cooperation and } \\
\text { team teaching in } \\
\text { multi-professional } \\
\text { expert groups }\end{array}$ & $\begin{array}{l}\text { - An inclusive statement of guiding principles shared by all who partake in the } \\
\text { school } \\
\text { - Multi-professional teams including teachers, special needs educators, social } \\
\text { and cultural workers, psychologists, therapists, teacherstudents etc. } \\
\text { - Multi-professional teams as learning teams that attend programs of inclusive } \\
\text { advanced education and staff training on a regular basis } \\
\text { - Intensive and continual attendance and broad interaction between diverse } \\
\text { learners and multi-profes sional teams embedded in the learning landscapes } \\
\text { - Peer-to-peer learning } \\
\text { - All day attendance of all teachers and educators }\end{array}$ \\
\hline $\begin{array}{l}\text { Com- } \\
\text { ponent }\end{array}$ & $\begin{array}{l}\text { Gui ding } \\
\text { principles }\end{array}$ & Examples of concrete measures \\
\hline 2 & $\begin{array}{l}\text { A school based on } \\
\text { principles of } \\
\text { democratic } \\
\text { participation and } \\
\text { equal } \\
\text { opportunities, the } \\
\text { furthering of } \\
\text { equity, including a } \\
\text { heterogeneous } \\
\text { student body that } \\
\text { is representative } \\
\text { of the diversity of } \\
\text { the local } \\
\text { community }\end{array}$ & $\begin{array}{l}\text { - An inclusive school from grade } 1 \text { to } 13 \text { that renounces the typical German } \\
\text { tripartite selection systemafter grade } 4 \text { or } 6 \\
\text { - Improvement of equal educational opportunities for all learners by } \\
\text { implementing international standards of anti-discrimination regarding } \\
\text { ethno-cultural background, gender, sexual orientation, social status, and } \\
\text { disabilities } \\
\text { - Democracy rooted in the "home base" of learners i.e., generous measures of } \\
\text { participation and negotiation in the making of all decision regarding the } \\
\text { contexts, relationships, and contents of learning } \\
\text { - Language policies that do justice to the appreciation of diversity and claims to } \\
\text { equity and anti-discrimination including a broad support for learners with } \\
\text { German as a second language } \\
\text { - A schoolstatement and policy against bullying } \\
\text { - A school statement and policy regarding the inclusion of parents, families, and } \\
\text { the neighborhood }\end{array}$ \\
\hline 3 & $\begin{array}{l}\text { A school with } \\
\text { high standards of } \\
\text { qualification for } \\
\text { all learners, } \\
\text { attempting to } \\
\text { achieve the best } \\
\text { possible degrees } \\
\text { with chances for } \\
\text { further education } \\
\text { and graduation }\end{array}$ & $\begin{array}{l}\text { - A thoroughgoing approach to learning by doing and achieving skills and } \\
\text { - Brompetencies } \\
\text { re/de/construction of curricula by teachers and learners (curricula workshops), } \\
\text { options of choice for learners regarding contexts, relationships, and contents } \\
\text { - Care for basic qualification in all relevant areas of learning (according to the } \\
\text { general curricula of the state) in combination with options and support for } \\
\text { higher qualification and specialization in areas of interest } \\
\text { - Internal differentiation including the specific attendance to individual learners, } \\
\text { the support, evaluation, and feedback regarding competencies that are arranged } \\
\text { in levels of achievement to provide support for personal excellency } \\
\text { - Organization of learning in formats that offer sufficient time for autonomous } \\
\text { learning (core discip lines of the curricula), cooperative learning in projects } \\
\text { (transdisciplinary themes of the curricula), learning in workshops of diverse } \\
\text { kinds (special interests and aptitudes) } \\
\text { - An inclusive architecture based on the principle that the classroom is dispens ed } \\
\text { by learning landscapes and more flexible and mobile forms of interaction }\end{array}$ \\
\hline 4 & $\begin{array}{l}\text { An all-day school } \\
\text { with a } \\
\text { well-balanced } \\
\text { rhythm of phases }\end{array}$ & $\begin{array}{l}\text { - Flextime regarding arriving and leaving } \\
\text { - Active and interactive learning as a rule combined with necessary phases of } \\
\text { instruction } \\
\text { - Emphasis on autonomous self-learning, cooperative learning in projects and }\end{array}$ \\
\hline
\end{tabular}




\begin{tabular}{|c|c|c|}
\hline & $\begin{array}{l}\text { of concentration } \\
\text { and relaxation, } \\
\text { work and play, } \\
\text { learning and } \\
\text { leisure, that } \\
\text { allows for healthy } \\
\text { and pleasant } \\
\text { living together }\end{array}$ & $\begin{array}{l}\text { workshops etc. (with at least } 30 \text { percent of time spent on self-learning and } \\
\text { projects each) } \\
\text { - For all grades, the workshops offer opportunities for inter-year learning } \\
\text { according to interests and aptitudes } \\
\text { - Renouncement of strict lesson periods in favor of flexible time management for } \\
\text { all learners in each learning landscape } \\
\text { - Easy transition from learning landscapes to terraces for outdoor activities } \\
\text { - A huge dining hall combined with a kiosk } \\
\text { - Locations for student companies like "fair trade shops," "bikers' workshops," } \\
\text { etc. }\end{array}$ \\
\hline $\begin{array}{l}\text { Com- } \\
\text { ponent }\end{array}$ & $\begin{array}{l}\text { Guiding } \\
\text { principles }\end{array}$ & Examples of concrete measures \\
\hline 5 & $\begin{array}{l}\text { An inspiring and } \\
\text { supportive } \\
\text { environment that } \\
\text { offers diverse } \\
\text { opportunities for } \\
\text { learning and } \\
\text { experience in } \\
\text { response to } \\
\text { diverse interests } \\
\text { and needs of } \\
\text { unique learners }\end{array}$ & $\begin{array}{l}\text { - Individualization of learning tasks in all learning formats including regard for } \\
\text { the individual backgrounds of unique learners, their interests, needs, capacities, } \\
\text { and ways of learning } \\
\text { - A general constructivist approach to learning that prefers construction over } \\
\text { instruction and includes, at least, the following as pects: } \\
\text { A multi-perspectival approach to learning that does justice to diverse } \\
\text { viewpoints in learning } \\
\text { A multi-modal approach to learning that favors diverse ways of learning for } \\
\text { diverse learners } \\
\text { An open-ended approach to learning that takes diverse results of learning } \\
\text { into account } \\
\text { - A network-like approach to learning that takes advantage of diverse media as } \\
\text { resources for active and constructive use }\end{array}$ \\
\hline 6 & $\begin{array}{l}\text { A school that } \\
\text { considers all } \\
\text { learners as unique } \\
\text { individuals with } \\
\text { special interests } \\
\text { and needs that } \\
\text { require } \\
\text { educational } \\
\text { support for } \\
\text { effective growth }\end{array}$ & $\begin{array}{l}\text { - Diagnostics regarding the starting points of individual learners combined with } \\
\text { specific diagnostics for special needs } \\
\text { - Formulation of individual target agreements combined with processes of } \\
\text { consultation and feedback oriented towards the achievement of personal } \\
\text { excellency } \\
\text { - A multi-professional team that especially includes teachers trained in special } \\
\text { needs education and other experts in individual support of all kinds (like } \\
\text { psychologists, therapists, social and cultural workers, etc.) } \\
\text { - Procedure according to the criteria of participation stated by the WHO (ICF) } \\
\text { - Consultation of external experts when needed }\end{array}$ \\
\hline 7 & $\begin{array}{l}\text { A complex } \\
\text { approach to the } \\
\text { evaluation of } \\
\text { performances that } \\
\text { includes the } \\
\text { participation of } \\
\text { learners in the } \\
\text { very processes of } \\
\text { assessment }\end{array}$ & $\begin{array}{l}\text { - Feedback on individual as well as collaborative progress in learning } \\
\text { - Evaluation not only as grading and rating but as support in the process of } \\
\text { learning and growth } \\
\text { - Transparent evaluation that prefers explicit, elaborated verbal feedback over } \\
\text { assigning marks } \\
\text { - Evaluation as embedded in the processes of teaching and learning } \\
\text { - Evaluation based on stated competencies, transparent to the students and } \\
\text { - parents } \\
\text { - Evaluation based on levels of performance with a view to personal excellency } \\
\text { - "Fell as performances } \\
\text { - Feed up, feedback, feed forward" as necessary components in a continual } \\
\text { - A combination of diagnostics of starting points, semiannual target agreements } \\
\text { and evaluation interviews } \\
\text { - Consulting in face-to-face conversation wheneverneeded }\end{array}$ \\
\hline & $\begin{array}{l}\text { Gui ding } \\
\text { principles }\end{array}$ & Examples of concrete measures \\
\hline 8 & $\begin{array}{l}\text { A reconstructed } \\
\text { architecture and }\end{array}$ & $\begin{array}{l}\text { - The school is constructed as a new building based on the inclusive educational } \\
\text { program especially developed in relation to the local contexts }\end{array}$ \\
\hline
\end{tabular}




\begin{tabular}{|c|c|c|}
\hline & $\begin{array}{l}\text { design of the } \\
\text { school which is } \\
\text { not based on the } \\
\text { idea of classroom } \\
\text { but on the concept } \\
\text { of learning } \\
\text { landscapes for all } \\
\text { grades, each } \\
\text { including up to } \\
\text { 100 students and a } \\
\text { multi-professional } \\
\text { team of experts }\end{array}$ & $\begin{array}{l}\text { - All areas are accessible for people with impairments including special attention } \\
\text { to conditions of light and sound } \\
\text { - The concept of learning landscapes includes flexible divisions of spaces, } \\
\text { multi-functional rooms and open spaces for groups, presentation areas, } \\
\text { a base for the multi-professional team, kitchen and restrooms for all } \\
\text { - In between two learning landscapes there are lecture halls that are also used for } \\
\text { multi-functional purposes like group work, projects, performances, theater, } \\
\text { dance, gymnastics, etc. } \\
\text { - There are workshops and studios for arts, music, cooking, projects of student } \\
\text { companies } \\
\text { - There are laboratories for the sciences } \\
\text { - Library and open spaces for exhibitions } \\
\text { - There are a dining hall and a central auditorium that can be combined for } \\
\text { special purposes like celebrations, huge performances, theater, etc. } \\
\text { - There are two gyms, one usable by three large groups at a time in parcelled } \\
\text { areas, anotherfor single group use } \\
\text { - Clustered areas and group rooms for administrators } \\
\text { - Seminar rooms for university students in teacher training and teachers in } \\
\text { in-service training equipped with video casting from the learning landscapes } \\
\text { - Rooms for therapy and bath care }\end{array}$ \\
\hline 9 & $\begin{array}{l}\text { A school that is } \\
\text { open to all } \\
\text { relevant } \\
\text { dimensions of the } \\
\text { life-world }\end{array}$ & $\begin{array}{l}\text { - Inclusive education implies processes of bringing elements of the life-world } \\
\text { into the school as well as participating actively in processes outside the school } \\
\text { in the local communities and public affairs of Cologne } \\
\text { - Student companies that operate in the urban neighborhood } \\
\text { - Involvement of a large number of university teacher students in all activities of } \\
\text { the school } \\
\text { - The school in part offers access and services to the larger public } \\
\text { - The school has a comprehensive theater program with regular public } \\
\text { performances } \\
\text { - The school cooperates with diverse local shops, firms, and companies } \\
\text { The school entertains many networks with local groups, organizations, and } \\
\text { projects of civil engagement, support, and care (e.g., refugee work) }\end{array}$ \\
\hline 10 & $\begin{array}{l}\text { Multi-professiona } \\
1 \text { teams based on } \\
\text { mutual } \\
\text { consultation, } \\
\text { professional } \\
\text { supervision and } \\
\text { broad evaluation }\end{array}$ & $\begin{array}{l}\text { - A consultation approach based on principles of participation, collegial } \\
\text { exchange and support, professional coaching when needed } \\
\text { - Supervision by independent experts, continually as well as in response to } \\
\text { specialdemands } \\
\text { - A combination of internal and external evaluation regarding learning } \\
\text { achievements } \\
\text { - Accompanying research by members and resources of the University of } \\
\text { Cologne in combination with teacher training programs } \\
\text { - Public debate about processes and results }\end{array}$ \\
\hline
\end{tabular}

Figure 4. 10 Components of inclusive Education at the IUS

\section{New Learning in a New School}

Learning in the Helios-School takes place in formats that allow for sufficient time for autonomous learning in the core disciplines, cooperative learning in projects and transdisciplinary themes, as well as learning in workshops of diverse kinds regarding special interests and aptitudes of the students. The architecture of the school must correspond with these needs. Let us have a closer look at the design for learning landscapes. In figure x you see two learning landscapes for students of grade five and six. The representation closely resembles the final architectural structure. Containing approximately 100 students and the multi-professional team up to 20 persons (including teacher training students), learning in these areas comprises a complex combination of opportunities, resources, and possible activities with many participants. The spatial ratio that underlies the calculation of the size of learning landscapes is 4 square meters per student. 


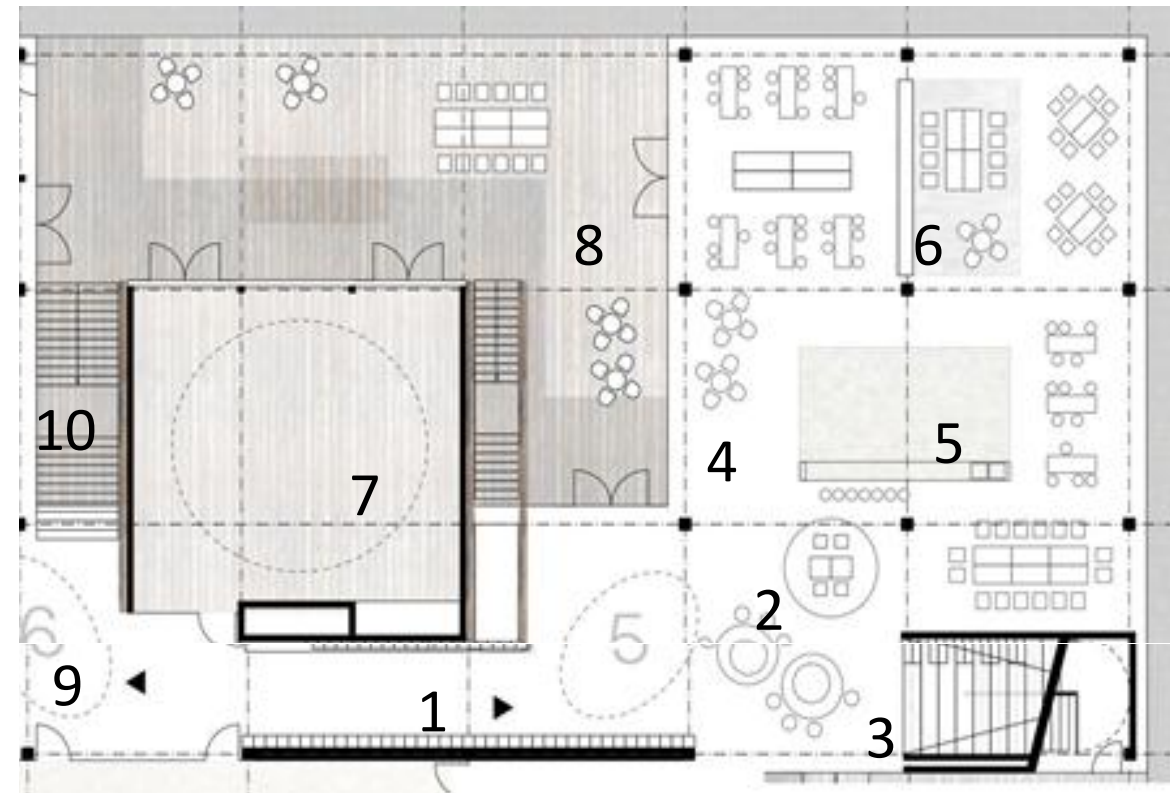

Figure 5. The Learning Environment of Grade 5 by Schilling architects

Key: 1 wardrobe / 2 high tables and think tank / 3 small foru m with stairs / 4 mu lti-functional open space for learning with group rooms / 5 rest rooms with kitchen at the backside / 6 base for the multi-professional team / 7 auditorium/lecture hall / 8 terrace / 9 connecting floor to grade 6 / 10 outer staircases

Let us consider a possible day of learning in one such learning landscapes told by a fictitious student:

"In the morn ing, I arrive in flex time depending on my parents' duties. Through the common entrance, designed in a generous manner that allows for lots of light and even contains a big patio, I take the elevator up to the learning landscape where my home base is located. Other students take the stairs. I take a left turn to the wardrobe for grade 5. I take of my shoes and slip into my house shoes. I have my personal locker where I can change clothes and store my learning materials. With other students, I enter the reception area that leads to my ho me base. It consists of the open learning landscape with light and flexible furniture of many kinds combined with two stable rooms and the base for teachers and staff. There are unisex restrooms for students and teachers alike. We have clear rules to keep them tidy. The teachers have their own base for assembling and preparing their work. The wall of the base is transparent so we all can see who is there and they can see us. At all times, there is somebody at the base whom we may ask for support and assistance. In the stable rooms, we can assemble as learning groups, discuss or use them when we want to work or relax in silence. When parents are present we can use these rooms for conversation, too.

In the morning, I arrive as an early bird because my parents have to go to work before eight. First thing for me is to take my self-learning materials and move to a place where I like to work on my own or with friends. When I am involved in a learning project I usually work in a group of four. Our stem group consists of four such small groups i.e., 16-17 students. All together we are six stem groups in our learning landscape. Each stem group has at least one teacher and one teacher student. They are supplemented by others from the multi-professional team like social workers, educators and so on.

When flextime is over all other students have arrived. Now we have time slots for three comprehensive learning formats. Each format plays a role every day but the sequence and the focus are different from day to day:

Today, we first have time for self-learning inspired and structured by assignments in the learning landscape. We use the self-learning materials combined with methods for screening competencies (including a raster of stated competencies on different levels of achievement). These methods help me to control my learning processes by myself, but of course I also get the assistance and feedback of my teachers and peers. In this phase of learning I am free to choose the area and location in the learning landscape myself. Sometimes I prefer to choose a place where I can be on my own like the think tank or the silent room or another relatively closed area. At other times, I wish to 
work and communicate more directly with other and therefore prefer going to a more open area. There are different options I can choose like the stairs forum, the lounge, the table areas, or the big auditorium. I learnt that I am less sensitive to noise than I had expected. However, this is only true when I work on an assignment that really interests me and brings me to a flow of learning. All major disciplines are involved in these times of self-learn ing. They give me the opportunity to start learning in my own pace and rhythm. Based on my previous understanding I can explore my best possible achievements on my own. Even if I know from comparison that other students are faster or slower, it doesn't matter for me now. The idea is that we all achieve basic competencies in every relevant area of learn ing. From that basis on there can be many differences of higher levels of achievement to attain. Regarding my learning process and the results I am up to, I can participate on every level. But self-learning is not a time to waste. It helps me to recognize that on every step I achieve I encounter new challenges and possibilities. The multi-professional team continually assists and supports me in all affairs. They observe my learning advances and help me to prepare for the final examination at the end of each learning phase to show the level I have attained. The learning materials are organized in ways that they first give a short theoretical input and then allow for sufficient time to practice, exercise, apply, and reflect what one has learnt. If I have questions concerning the input, I can always ask my peers or turn to the teacher. The portfolio that I employ for documenting and reflecting my learning is also useful for this preparation. This way I never felt lost behind the others so far. But when I would have a bad day and find it hard to work, I can get emotional support. I especially like our social worker because she has such a good sense of humor.

Our second time, slot today is dedicated to working on a learning project. It starts in the auditorium. This big room allows for gathering of all of us with enough space to move around, form groups, start conversations. It also has a stage on which the teachers and we ourselves can announce a project and give necessary information and instruction for further proceedings. The stage will also be the place where we can present our results at the end of the process. Today, our teacher prepares us for working on a new project regarding food production/consumption and climate change. It is connected with our former project on the greenhouse effect. With these projects, we students can always participate in the decision of what we want to learn and explore. For exa mple, we had a discussion after the last project and thought that it is important to take our own food behavior including the usual waste of food in many families closer into account. Our teachers accepted our interest and then prepared materials to start with a new project. We will now work on it for several weeks. In the auditorium, we start by forming sub-groups with special interests that can work in a combination of specialization and cooperation. Each group become experts in a selected field and then give their expert ise to the whole group of 100. Results are not only presented at the end of the process, but will repeatedly be shown and discussed in exchange between the groups and with the teachers. For this reason, we come together now and then in the auditorium while in the learning process we are free to use the whole learning landscape and other learning areas inside and outside the school. For research, we can use not only the library but also the internet by unlimited WLAN. For documentation and presentation, we have many media we can use like smartboards, flipcharts, pin-boards, digital media in all forms. We are used to documenting our learning results in e-portfolios. For projects, we use Wikipedia in the form of an intranet, too. The school has its own platform in this kind of Wikipedia where only the students and teachers can write and rewrite articles and other presentations. In my project team like in other small groups, heterogeneity is the rule. The principle is that we complement each other with our different talents, skills, and capacities. All help each other with their strengths. Therefore, the multi-professional team takes measures to group and continuously re-group our teams according to strengths and weaknesses. In the course of time I come to know many of the other students by changing team cooperation. The team spirit is especially important to us. We repeatedly discuss about ways to improve our teams and cope with conflicts. There is a special method used for this intention. We call it the "Home Base Council." It is based on the ideas of self-governance and counseling in teams. It comes together on a regular basis. For the stem groups this means more or less daily, for the home base group of 100 in our learning landscape it means as often as needed.

The third timeslot is spent in the workshops. For the whole timeslot, heterogeneity and mixture of age groups is the rule. Older students and professionals from different contexts work and learn together with us. There are obligatory and voluntary areas of learning. For instance, regarding sports which is an obligatory area for all of us, I have chosen table tennis. The leader of our course is a student from the upper secondary level. There are other courses in which parents and professionals, say from sports clubs, take a leading role. In the moment, I am also a member of a bicycle shop, a photo shop, and a choir. Every half year, we have a gathering of our home base group where we discuss and decide together what range of workshops will be offered and organized for the next six months. In advance, everybody is free to make suggestions for new workshops. The multi-professional team prepares the process and makes suggestions as to possible persons for leadership. After the decision is made in the home base group, they make a plan regarding the organization and realization. 
On my very first day in the school, my impression was that the home base group is incredibly huge. How can you connect with 100 other students in a way that you do not los e yourself in the mass? How can you relate with them in reliable ways? It was helpful for me to learn that there a step by step structure in which we first cooperate in small groups of four and then, on the second level, in stem groups of 16-17. The home base constitutes the third level and I found that it was sufficient for me and the other students to come to know this comprehensive group over the time.

Our small groups as well as stem groups are smaller than a usual classroom. Our school has totally replaced the traditional classroom system by the concept of learning environments. An important element of this new concept is that we can continuously build and re-build our learning spaces ourselves. For instance, we have movable and flexible racks that can be used as temporary walls that frame learning spaces for groups of all sizes. Students can sit inside the racks, but they can also use them to pin posters or other materials. You can arrange the m in ways that you get a closed circle for silent teamwork and conversation, but you can also put them in line in order to demarcate larger areas. In the design of the learning landscapes, generally, furniture has been chosen very carefully. There are different types of furniture adapted to specific learning zones each. Sitting as well as learning does not always fit the same size. Also the learning areas and their specific furniture and equipment also serve to coordinate noise and silence according to learning needs. If one has an especially urgent need for silence, one may for example go into the think tank that looks like a kiosk with windows you can close or open. We sometimes also love to use it for role-play and other group activities. Each learning landscape has two group rooms big enough to contain one stem group. They have class walls so you can always see if they are occupied. When you are in them with your group, they provide an atmosphere of concentration and privacy.

Most of the time in the first and second learning time slots mentioned above is spent in our home base. But there are more learning areas we can use. Besides the library, we use science laboratories for more extensive experiment, the workshops for arts and music, the huge hall for theater and other presentations, the four sports halls for all physical activities, the students' companies and their rooms for business activities, and the laboratory kitchen for cooking. But we also go outside. Most of our activities and projects involve explorations in the urban neighborhood outside school.

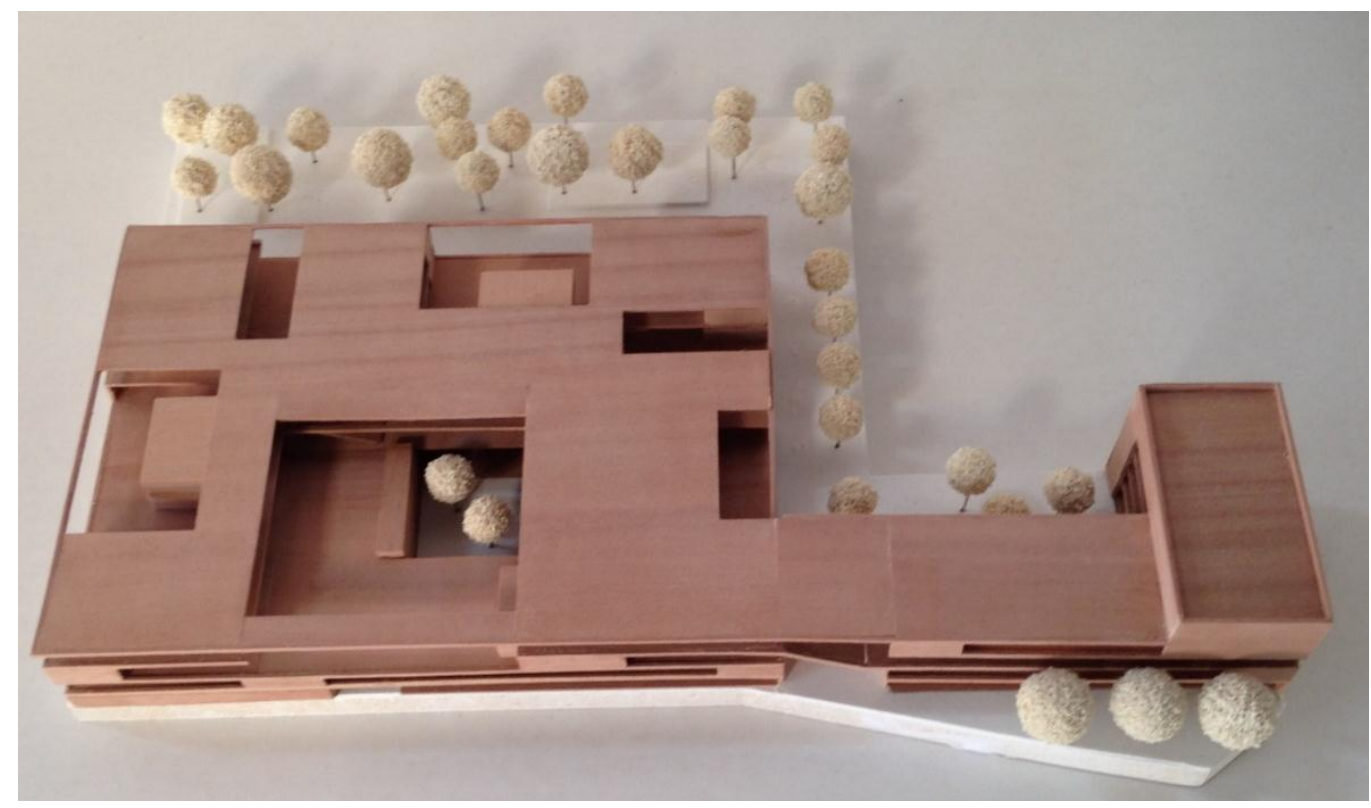

Figure 6. The IUS with incisions for terraces (schoolyards) by Schilling architects

In our learning landscape, there is a kitchen unit for smaller breaks. What I like most are our grand terraces that are directly accessible from the learning landscape. In the summer, I like working outside in fresh air. The architects have used the urban area on which the school is built for providing generous yards and terraces. Because of its location on a densely populated urban site, the school is equipped with less ground space than an average school in 
Germany would be. Although we therefore don't have extensive meadows and gardens, the architectural design offers much light in all rooms and invites for outdoor activities.

We all come together for lunch in the dining hall. But this hall is not only for eating. It can be connected easily with the assembly hall, thus constituting a great theater hall with an excellent stage. Theater plays a central role in the school's concept and program, therefore we all are quite used to standing on the stage. Through our performances to the school and larger public we earn amounts of money that can be used to fund the theater and its equipment.

All in all, I can say that everybody in the school takes my learning development and progress seriously. This includes that I regularly receive feedback, on the basis that I present my weekly schedule and time sheets. The control of tasks and results is always direct and includes the exchange between me and my teachers and peers. I like most the presentation of projects when we get individual as well as group feedback. It gives me a good feeling that my achievements and results are being appreciated by my peers and by the experts. A great advantage of our teamwork in the learning landscape is that even if a teacher or other expert should be ill, this does not result in the cancellation of lessons. The team can always compensate the absence of individuals. The team also works against the usual pressures of homogenization, standardization, and competition. It is always possible to learn in diverse ways and different speed. What is important is that we - as individuals and as groups - achieve the goals that we ourselves have formulated in our learning schedules in coord ination with our teachers. The basic principle is one of mutual support rather than of competition.

The school day ends in flextime. I don't have to wait long since my parents come from work not later than the end of school. By the way, they must pick me up because I am a wheel chair user. You may ask yourself how it is that I can play table tennis. It is possible because each time one of my peers picks up the balls for me. And we have a ball machine, too, that returns them to me. It's easier than you may guess.

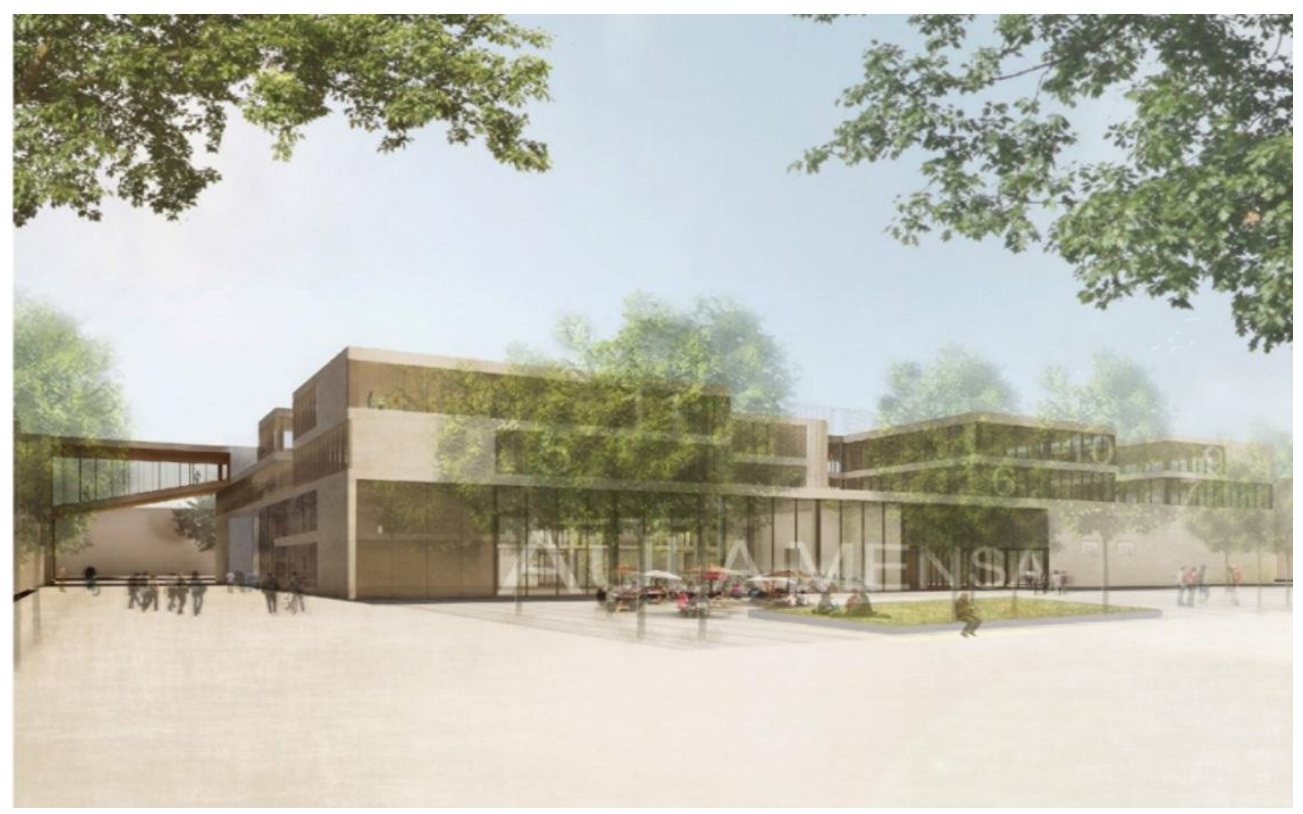

Figure 7. The Back of the School by Schilling Architects. In the Base, there are Dining and Assembly Halls

The fictitious story helps to illustrate how school can change. One could equally tell the story from the perspective of teachers. They, too, experience great changes in teaching and learning as well as in the whole school atmosphere and the attitude they themselves take towards the students, parents, colleagues, as well as the school and its many contexts. Team teaching and working in multi-professional teams implies all-day attendance, intensive preparation and care regarding all learning materials and tasks, the development of good and authentic relationships and mutual care for open, cooperative, communicative, and constructive learning environments. To frame such changed conditions, the four mentioned learning formats have proven to be effective: 
(1) Instruction should be given when necessary but it should not be the dominating princip le. The school takes pains to provide forms of instruction that do justice to the individual needs of learners instead of simply following a one-size-fits-all approach.

(2) Autonomous learning under conditions of diversity and participation is the core principle of an inclusive school (roughly $30 \%$ of learning time). This includes the core disciplines of the curriculum as well as the many and diverse interests, talents, skills, and capacities of learners. It implies different levels of learning tasks and different use of materials by different learners.

(3) Learning projects are the main principle for furthering cooperative learn ing in heterogeneous groups (roughly $30 \%$ of learning time). They have the advantage of providing occasions for transdisciplinary the mes to be followed by ways of division of work, exchange of experiences, combination of interests, appreciation of diverse skills and forms of knowledge as well as mutual development of skills and expansion of knowledge.

(4) Workshops offer conditions for further developing and exercising special interests and aptitudes for all students (roughly 20-25\% of learning time). Two essential principles characterize learning in this format. First, the contents and forms of workshops depends on decisions made by students and teachers in processes of deliberation based on the equal participation of all. Second, students from all grades come together in the workshops. Cooperation across ages is possible and appreciated.

\section{Obstacles in the Process of Establishing Inclusive Schooling}

It is a continual experience that all four formats are necessary for inclusive schooling. We already find the m, mo re or less explicitly, in Dewey's model and we encounter them today, under changed conditions and contexts of learning. Likewise, we find many obstacles in all modern societies for establishing and implementing inclusive education. In the German context, the following obstacles must be taken into account. They refer to more or less general conditions of schooling in modernity. Therefore, it seems reasonable to suppose that similar problems have to be met in other contexts, too.

(1) System of education: Germany is notorious for its selective and compartmentalized school system. A lready at the age of ten, students are usually tracked into largely impenetrable compartments. Compulsory schooling is divided into comprehensive education for levels one to four, followed by education for levels five to ten in separated tracks. For the Helios-School this meant that it had to be build up in two steps, first a primary school with two parallel classes, and then a secondary school with four parallel classes to admit further students from other primary schools. The Helios-School avoids tracking. But it cannot neglect the legal obligation that all secondary schools are obliged to admit students from all primary schools with equal chances at level five. Therefore, the structure of a small primary component and a larger secondary component was enforced by the overall system.

(2) Tradition of exclusion: In accord with tracking and the German four-partite school system (Hauptschule for "low level," Realschule for "middle level," Gymnasium for "high level," special needs schools) there has been a long tradition of separation and exclusion that implies not only a history of practices but also has become internalized by many as mental habits. Today, inclusive education has to struggle against the condition that many teachers and future teachers have themselves been socialized in the compartmentalized and exclusive system.

(3) Average size of class: Research on learning shows that an efficient size of class in inclusive schooling should not be larger than 20 students. In Germany as well as in some other countries the average size is close to 30. This number alone indicates that a relatively rich country like Germany until the present day seriously underfunds its educational system. But size of class is not the only decisive thing. Equally important is the overall ratio of teachers and students. The Helios-School has found a compromise with an average size of 25 under conditions of team teaching. All possible forces and resources, including the all-day attendance of teachers and other experts, the presence of one teacher student per teacher, the diverse capacities of the multi-professional team are all employed to increase the teacher-student-ratio in quantity and quality.

(4) Principles ofleadership: Germany has a long tradition of hierarchical organization throughout the educational systems going back as far as the Prussian authoritarian state of the $19^{\text {th }}$ century. Until the present day, democratic and participatory practices in school encounter many obstacles and depend on the goodwill and personal engagement of all especially those in leading positions. The civil servant status of teachers involves, in the German system, that on the one hand state laws and policies regulate and constrain the selection of leaders and their opportunities and responsibilities of acting as leaders. From a democratic point of view, chances of participation, teamwork, and shared leadership are largely restricted. On the other hand, the 
authority of leadership to counteract anti-democratic and discriminatory behaviors of staff me mbers is weak because every teacher is protected in the bureaucratic order involving his or her guaranteed life-long job and status.

(5) Teamwork and working hours: In Germany, the average school is not prepared for teamwork and all-day presence of all staff members. So far, the average expectation of individual teachers as well as the school as an organization is that they fulfill the obligatory number of teaching hours in the curriculum and then do the preparation for the next day alone at home. To change this scheme of work, which seems largely ineffective from an inclusive standpoint, there must be an effective insight and agreement on the part of collectives of teachers, leaders, other staff me mbers, that is worthwhile to invest time and energy to overcome isolation and narrow focus on one's own teaching. Teamwork and whole day presence are key elements of a school that is devoted to establishing and furthering inclusive schooling and education.

(6) Grading: In heterogeneous groups of learners, grading can no longer follow a one-size-fits-all approach. However, there are deep-seated habits of grading by numbers without giving qualitative and diversified feedback to unique and divers learners. An inclusive school must provide new forms and formats of grading and developing habits of mutual and transparent evaluation. It cannot evade state-regulated norms for grading by numbers, but it can supplement them with more qualitative and communicative responses to learners' achievements.

(7) All-day-school: In Germany, there is a long tradition that school - including all tracks in the tripartite system - starts in the morning and ends around 1 or $2 \mathrm{pm}$. The afternoon used to be leisure time for teachers and students. It is not easy to overcome this tradition, which is relatively unique in international comparison. Challenges imply the change of institutional structures as well as change of habits, expectations, and vested privileges. In the current educational reforms, there is a tendency called "open all-day-school" (offener Ganztag) which means that the privileges remain for the teachers while roughly 70 percent of students participate in the provision of afternoon activities conducted by educators and social workers that are not part of the teaching staff. The challenge for inclusive education, in the sense that the Helios -School tries to practice it, is to realize a broader and more generous concept of all-day-school in which all activities are rhythmized in a comprehensive approach. The multi-professional staff of teachers, educators, social workers etc. provides a school-life which includes phases of learning and phases of leisure or other activities spread across the day. This kind of approach is called a "connected all-day-school" (gebundener Ganztag).

(8) Teacher training school: Since 2015 the University of Cologne connects its teacher training program with the Helios-School. The University offers an inclusive profile for teacher students who have the opportunity to start their training in special courses that prepare them for practice phase and complete practice semester in the Helios-School. There is a close cooperation between University teaching staff and the teachers of the school which includes joint selection, education, and training of students. Against the background of the long tradition of separation between theory and practice, universities and schools, in German teacher education, this concept is extraordinary and path breaking, even if so far it only involves a smaller group of students.

\section{References}

Dewey, John: Collected Works. Edited by Jo Ann Boydston:

The Early Works (EW 1-5): 1882-1898. Carbondale \& Edwardsville: Southern Illinois University Press / London \& Amsterdam: Feffer \& Simons.

The Middle Works (MW 1-15): 1899-1924. Carbondale \& Edwardsville: Southern Illinois University Press.

The Later Works (LW 1-17): 1925-1953. Carbondale \& Edwardsville: Southern Illinois University Press.

\section{Other References}

Bauman, Z. (2000). Liquid Modernity. Cambridge: Polity Press.

Garrison, J. (ed.) (2008). Reconstructing Democracy, Recontextualizing Dewey. Pragmatism and Interactive Constructivismin the Twenty-first Century. New York: State of the University of New York Press.

Garrison, J., Neubert, S., \& Reich, K. (2012). John Dewey's Philosophy of Education. An Introduction and Recontextualization for Our Times. New York: Palgrave Macmillan.

Garrison, J., Neubert, S., \& Reich, K. (2016). Democracy and Education Reconsidered. Dewey after One Hundred Years. London/New York: Routledge. 
Green, J., Neubert, S., \& Reich, K. (eds.). Pragmatism and Diversity. Dewey in the Context of Late Twentieth Century Debates. New York: Palgrave Macmillan.

Green, J.M. (1999). Deep Democracy. Lanham, Boulder, New York, Oxford: Rowman and Littlefield.

Hickman, L., Neubert, S., \& Reich, K. (eds.) (2009). John Dewey between Pragmatism and Constructivism. New York: Fordham.

Kricke, M., \& Reich, K. (2016). Teamteaching. Weinheim: Beltz.

Reich, K. (2012). Inklusion und Bildungsgerechtigkeit. Weinheim: Beltz.

Reich, K. (2014). Inklusive Didaktik. Weinheim: Beltz.

Reich, K. et al. (2015). Eine inklusive Schule für alle - Das Modell der Inklusiven Universitätsschule. Weinheim: Beltz.

Stiglitz, J. (2012). The Price of Inequality. New York/London: Norton \& Company.

\section{Notes}

Note 1. The first three chapters go back to talks that Dewey gave in 1899 to parents of the "Elementary School."

Note 2. Considering how many ideas in Hentig's book Die Schule neu denken (2003) stem actually from Dewey, it is surprising that Hentig quotes Dewey only occasionally and does not sufficiently clarify his references.

Note 3. Cf. for example Hickman/Neubert/Reich (2009), Green/Neubert/Reich (2012), Garrison (2008), Garrison/Neubert/Reich (2012, 2016).

Note 4. The book "Eine in klusive Schule für alle - Das Modell der Inklusiven Universitätsschule Köln" (Reich et al. 2015) gives many accounts of what negotiation and decision making meant in details.

Note 5. https://www.lib.uchicago.edu/e/spcl/centcat/fac/facch08_01.html 